\title{
Psychosocial Impacts of Imprisonment among Youth Offenders in Correctional Administration Center, Kellem Wollega Zone, Ethiopia
}

\author{
Yirgalem Bekele Tasisa ${ }^{1}$, Kogila Palanimuthu ${ }^{2}$ \\ ${ }^{1}$ Lecturer, Department of Psychology, School of Education and Behavioral Sciences, Dambi Dollo University, \\ Oromia, Ethiopia, ${ }^{2}$ Assistant Professor, Department of Nursing, College of Medicine and health sciences, Dambi \\ Dollo University, Oromia, Ethiopia
}

\begin{abstract}
A research study was conducted to assess the psychological impact of imprisonment among youth offenders at selected correction administrative center, Kellem Wollega zone, Ethiopia.

The objectives were to assess the respondent's socio-demographic characteristics, to investigate the psychosocial impacts of imprisonment on Youth Offenders and to identify the difference on Youth imprisonment level with the residence and gender of offenders.

Crosses sectional study was conducted with 83 youth offenders were selected by systematic sampling technique. The data were collected by using standardized questionnaires. The collected data was tabulated and analyzed with SPSS. Descriptive and inferential statistics were used.

Researchers observed that causes of imprisonment in three different categories as follows: $42(50.6 \%)$, $18(21.7 \%)$ and $23(27.7 \%)$ of the respondents reported psychological, social and economic interconnected reasons respectively. Psychological impacts of imprisonment as tracks: 68(81.9\%), 59(71.1\%) of the respondents reported diminished sense of self-worth, personal value due to imprisonment and Self-harm and drug abuse are the result of long periods of time spent in the prison correspondingly. It is vital and utmost necessary to identify the level of psychological impact and alleviate the fear and other associated symptoms and arrange for counselling to provide positive metal health.
\end{abstract}

Keywords: Psychological impact, Imprisonment, youth offenders, Ethiopia.

\section{Introduction}

Youth is best understood as a period of transition from the dependence of childhood to adulthood's independence. The United Nations defines 'youth',

\section{Corresponding Author:}

\section{Kogila Palanimuthu}

Assistant Professor, Department of Nursing, College of Medicine and Health Sciences, Dambi Dollo University (Government of Ethiopia), Kellem Wollega Zone, Oromia, Ethiopia-260

e-mail:kogila@dadu.edu.et

Phone: +251946266424

What's app Number: 09791868988 as those persons between the ages of 15 and 24 years (http://undesadspd.org/Youth.aspx). Ethiopia's national youth policy (2004) defines youth as those aged between 15-29. The national youth policy of Ethiopia was adopted in 2004. The national youth policy (2004) aims to enable youth to participate, in an organized manner, in the process of building a democratic system, good governance and development endeavors ${ }^{1,2}$.

Young people are expected to take on more mature roles and responsibilities and figure out how to become healthy and responsible members of society. Adult outcomes depend heavily on what happens during these years because the experiences of adolescence lay the foundation for what individuals will be able to accomplish in the next stage of their lives ${ }^{3}$. Making 
a successful transition from the dependency of adolescence to the self-sufficiency of adulthood is a process that requires the coordination of many skills. These capacities are epitomized in a concept called psychosocial maturity (Greenberger, 1984) and require development across three important domains: mastery and competence, interpersonal relationships and social functioning, and self-definition and self-governance ${ }^{4}$. To achieve sufficient psychosocial maturity and, along with it, the abilities to function as independent and productive adults, youths in contemporary industrialized society need to complete a series of developmental tasks in each of these three areas ${ }^{5}$.

However, young people often involved in crime which lead them fall in imprisonment which affects their psychosocial maturity. There are a number of factors that lead to commit criminal behavior for a person at an everywhere in every time ${ }^{6}$. Among different factors social, psychological influences that affect youth to commit crime like, personality disorders, family related influences, sibling influences; spiritual and cultural influences and many other factors that affect youth to commit crime ${ }^{7}$.

Ethiopia is one of the developing countries where the majority of the people live below the poverty line. Young people constitute the majority of the poor. Moreover, the wide spread poverty, rapid urbanization, drought and famine, armed conflict, destabilizations of family life etc. have left millions of children in Ethiopia without care and protection ${ }^{8-11}$. A Part of this, Ethiopia is a country where traditional values have existed for centuries and deep rooted. These and other related sociocultural factors have led to the abuse, neglect and/or mal-treatment of children in Ethiopia ${ }^{12}$. It is not only the increase in number that should be of concern, but also the seriousness and the proportion of offenses committed by young people as compared with adults ${ }^{13}$. In Ethiopia, a survey research done in urban centers have shown many street boys were migrants from the surrounding rural areas who moved to the cities in search of employment and education when they failed to get what they wanted they stayed on the streets and started begging and or doing odd jobs which lead them to fall in crime ${ }^{14-17}$.

\section{Objectives:}

General Objective: The general objective of the study was to assess the psycho-social impacts of imprisonment on youth offenders in correctional administrative center, kellem wollega zone correctional administration office

\section{Specific Objectives:}

- To assess the respondents socio-demographic characteristics

- To investigate the psychosocial impacts of imprisonment on Youth Offenders

- To identify whether there is difference on Youth imprisonment level by the residence and gender of offenders

\section{Materials and Method}

Mixed method of research approach and descriptive design was adopted. The source population was all the imprisoned youth found in correctional administrative center, Kellem Wollega Zone during the study period. Youth's offenders who satiating the inclusion principles such as age group between 18-29 years with a simple random sampling technique participants were chosen for the study.

Sample size determination and sampling procedure: Neuman (1997) pointed out for conventional social science researchers for selecting representative samples for quantitative studies, if the study population is 1000 or under, the sample ratio would need to be about $30 \%$. Therefore, based on this guide, the sample size was determined for this study. From the secondary data source of kellem wollega zone correctional administration Centre target population was 275 , the following $30 \%$ of target population found in the prison were selected as sample size means 83 samples through systematic sampling technique.

Table 1: Population and sample selection

\begin{tabular}{|l|c|c|c|c|c|c|c|c|}
\hline Label & \multicolumn{4}{|c|}{ Target population } & \multicolumn{4}{c|}{ Sample } \\
\hline \multirow{3}{*}{$\begin{array}{l}\text { Youth Offenders at } \\
\text { that time in prison of } \\
\text { KWZCAO }\end{array}$} & Sex & Rural & Urban & Total & Sex & Rural & Urban & Total \\
\cline { 2 - 10 } & $\mathrm{M}$ & 140 & 116 & 256 & $\mathrm{M}$ & 40 & 33 & 73 \\
\cline { 2 - 10 } & $\mathrm{F}$ & 12 & 7 & 19 & $\mathrm{~F}$ & 6 & 4 & 10 \\
\cline { 2 - 10 } & Total & $\mathbf{1 5 2}$ & $\mathbf{1 2 3}$ & $\mathbf{2 7 5}$ & $\mathbf{T}$ & $\mathbf{4 6}$ & $\mathbf{3 7}$ & $\mathbf{8 3}$ \\
\hline
\end{tabular}

Source: Kellem Wollega Zone Correctional Administration Office 
Data collection instrument and Questionnaires development: The questionnaires were adopted from, Sisay (2016) \& Mebrihit (2008)in open source even though permission also obtained from the researchers. In order to gather relevant information for the study; some of questionnaires were developed by the researcher and validated the same. The questionnaire was translated into Afan Oromo and again translated back in to English, and comparisons was made on the consistency of the two versions. Recruited data enumerators were collected the necessary information by Structured Interview Schedule. The questionnaires were consisting of closed-ended and Likert scale items.

Data collection procedure: Data collectors were educated on the purpose of the research and method of questioning the offenders how to record the responses of the literate and not literate participants to minimize social desirability effects. Utterly 5 data collectors involved as one psychologist \& 4 police who were working in Kellem Wollega Zone Correctional Administrative Office. Data enumerators were piloted face to face interview. Researcher followed the doings of data collectors daily for the consistency of the data.

Data Processing and Analysis: Questionnaire was the instruments used for collecting relevant data from the participants. The overall analysis of collected data to describe the psychosocial impacts of imprisonment on Youth Offenders was done using the statistical analysis software 'Statistical Package for the Social Sciences' (SPSS) Version 23.0.

Specifically, Descriptive statistics was used to compute socio-demographic characteristics of respondents; and to analyses psychosocial impacts of imprisonment on Youth offenders while Independent sample t-test was used to analysis whether there is difference of Youth imprisonment level by gender and residence.

\section{Results}

This section focuses on examining the results intended to provide answers for the questions raised. The data which was collected from a total of 73 male and 10 female totally 83 Youth offenders was analyzed as follows.

\section{Part 1: General information of Youth offenders}

The total number of the youth offenders who participated in the study was 83 . Regarding their residential area, from the total 83 offenders, 46 (55.4\%) lives in rural area while 37 (44.6\%) lives in urban area. Out of the total offenders, $73(87.9 \%)$ were male while $10(12.1 \%)$ were female. Majority of the offenders 45 (54.2\%) were found within age interval of 26-29. The least number, $13(15.7 \%)$ of the offenders were found within the age interval of $18-20$ while $25(30.1 \%)$ of the offenders fall between age interval of 21-25.

Concerning the offenders job before their incarceration, majority of them were student $25(30.1 \%)$ and unemployed $24(28.9 \%)$ while the rest $8(9.6 \%)$, $10(12 \%)$ and $16(19.3 \%)$ were farmer, daily laborer, and merchant respectively.

Table 2: Educational information of Youth imprisonment $\mathrm{N}=83$

\begin{tabular}{|l|l|c|c|}
\hline Variable & Response & Frequency & Percentage \\
\hline & Grade 5-8 & 30 & 36.1 \\
Your Educational status & Grade 9-12 & 30 & 36.1 \\
& Certificate & 14 & 9 \\
& Diploma \& above & 26 & 42.6 \\
\hline If your educational status is not at the level of your & Fail (lack of point in order to pass to & 35 & 57.4 \\
interest, what is the reason behind your educational & next educational status) & 14 & 40.0 \\
status? & Dropout & 10 & 28.6 \\
\hline & Economic problem & 3 & 8.6 \\
What is your main reason to dropout from school? & Make crime \& fail in jail & Lack of interest to learn & 22.9 \\
\hline
\end{tabular}


Educational information of Youth imprisonment was analyzed with descriptive statistics and discussed in detail in Table 2.

Table: 3 Socio-economic information of Youth imprisonment

\begin{tabular}{|c|c|c|c|}
\hline Variable & Response & Frequency & Percentage \\
\hline Are your parents alive? & $\begin{array}{l}\text { Yes } \\
\text { No }\end{array}$ & $\begin{array}{c}75 \\
8\end{array}$ & $\begin{array}{c}90.4 \\
9.6\end{array}$ \\
\hline From your parents who is alive? & $\begin{array}{l}\text { Both parents alive } \\
\text { Mother only } \\
\text { Father only }\end{array}$ & $\begin{array}{l}27 \\
32 \\
16\end{array}$ & $\begin{array}{l}36.0 \\
42.7 \\
21.3\end{array}$ \\
\hline $\begin{array}{l}\text { If your parents are alive do they } \\
\text { live together? }\end{array}$ & $\begin{array}{l}\text { Yes } \\
\text { No }\end{array}$ & $\begin{array}{c}20 \\
7\end{array}$ & $\begin{array}{l}74.1 \\
25.9\end{array}$ \\
\hline $\begin{array}{l}\text { Do you have positive relationship } \\
\text { with your parents? }\end{array}$ & $\begin{array}{l}\text { Yes } \\
\text { No }\end{array}$ & $\begin{array}{l}50 \\
25\end{array}$ & $\begin{array}{l}66.7 \\
33.3\end{array}$ \\
\hline $\begin{array}{l}\text { If you have no positive relations } \\
\text { with your parents, why? }\end{array}$ & $\begin{array}{l}\text { Because of my conduct problem, they do not like me } \\
\text { Because I use different substance abuse they do not like me } \\
\text { Because they do not fulfill my interest I do not like them }\end{array}$ & $\begin{array}{c}13 \\
2 \\
10\end{array}$ & $\begin{array}{c}52.0 \\
8.0 \\
40.0\end{array}$ \\
\hline
\end{tabular}

Here the descriptive analysis of socio-economic information of 83 youth offenders was analyzed as follows. Among the total 83 youth offenders, $75(90.4 \%)$ of them were their parents are alive while $8(9.6 \%)$ of them were their parents are not alive and other related details are clearly specified in Table:3.

\section{Part 2: Causes of Youth imprisonment}

Table 4: Close-ended items on Causes of Youth imprisonment

\begin{tabular}{|c|c|c|c|c|c|}
\hline Variable & Response & $\mathbf{F}$ & $\%$ & Mean & SD \\
\hline $\begin{array}{l}\text { Which of the following Psychological } \\
\text { related Causes of imprisonment are } \\
\text { the reasons for you to commit crime? }\end{array}$ & $\begin{array}{l}\text { Antisocial personality disorder anxiety and being angry } \\
\text { Uses of substance abuse like alcohol, chat, smoking } \\
\text { Personal behavior like aggressiveness \& conduct problem }\end{array}$ & $\begin{array}{c}23 \\
6 \\
13\end{array}$ & $\begin{array}{l}54.8 \\
14.3 \\
30.9\end{array}$ & 1.76 & 0.906 \\
\hline $\begin{array}{l}\text { Which of the following Social related } \\
\text { Causes of imprisonment are the } \\
\text { reasons for you to commit crime? }\end{array}$ & $\begin{array}{l}\text { Bad relationship with parents } \\
\text { Broken family (divorce, death of one parent or both, } \\
\text { migration) } \\
\text { Peers influence } \\
\text { Being orphaned }\end{array}$ & $\begin{array}{l}8 \\
3 \\
5 \\
2\end{array}$ & $\begin{array}{l}44.4 \\
16.7 \\
27.8 \\
11.1\end{array}$ & 2.06 & 1.110 \\
\hline $\begin{array}{l}\text { Which of the following Economic } \\
\text { related Causes of imprisonment are } \\
\text { the reasons for you to commit crime? }\end{array}$ & $\begin{array}{l}\text { Lack of basic needs due to lack of support } \\
\text { Lack of work opportunity }\end{array}$ & $\begin{array}{c}8 \\
15\end{array}$ & $\begin{array}{l}34.8 \\
65.2\end{array}$ & 1.65 & 0.487 \\
\hline $\begin{array}{l}\text { What is the type of crime that you } \\
\text { were found guilty currently/came to } \\
\text { this institution? }\end{array}$ & $\begin{array}{l}\text { Robbery/Stealing } \\
\text { Rape } \\
\text { Physical fighting } \\
\text { Damage to property } \\
\text { Gambling } \\
\text { Other }\end{array}$ & $\begin{array}{c}9 \\
4 \\
42 \\
14 \\
5 \\
9\end{array}$ & $\begin{array}{c}10.8 \\
4.8 \\
50.7 \\
16.9 \\
6 \\
10.8\end{array}$ & 3.81 & 1.142 \\
\hline
\end{tabular}


Part 3: Psychological impacts of Youth Imprisonment

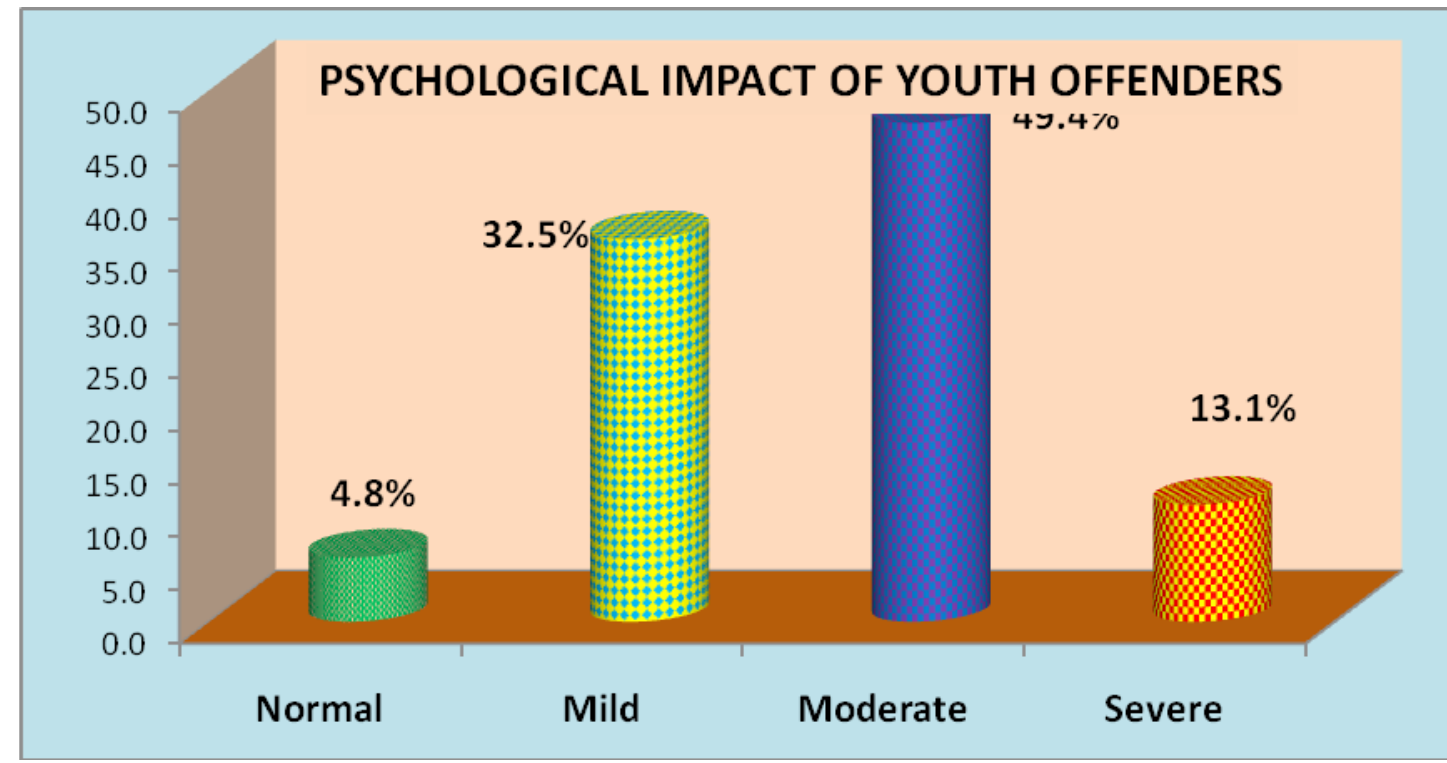

Fig: 1 Showing the Severity of psychological impacts of youth offenders

Part 4: Social impacts of Youth Imprisonment

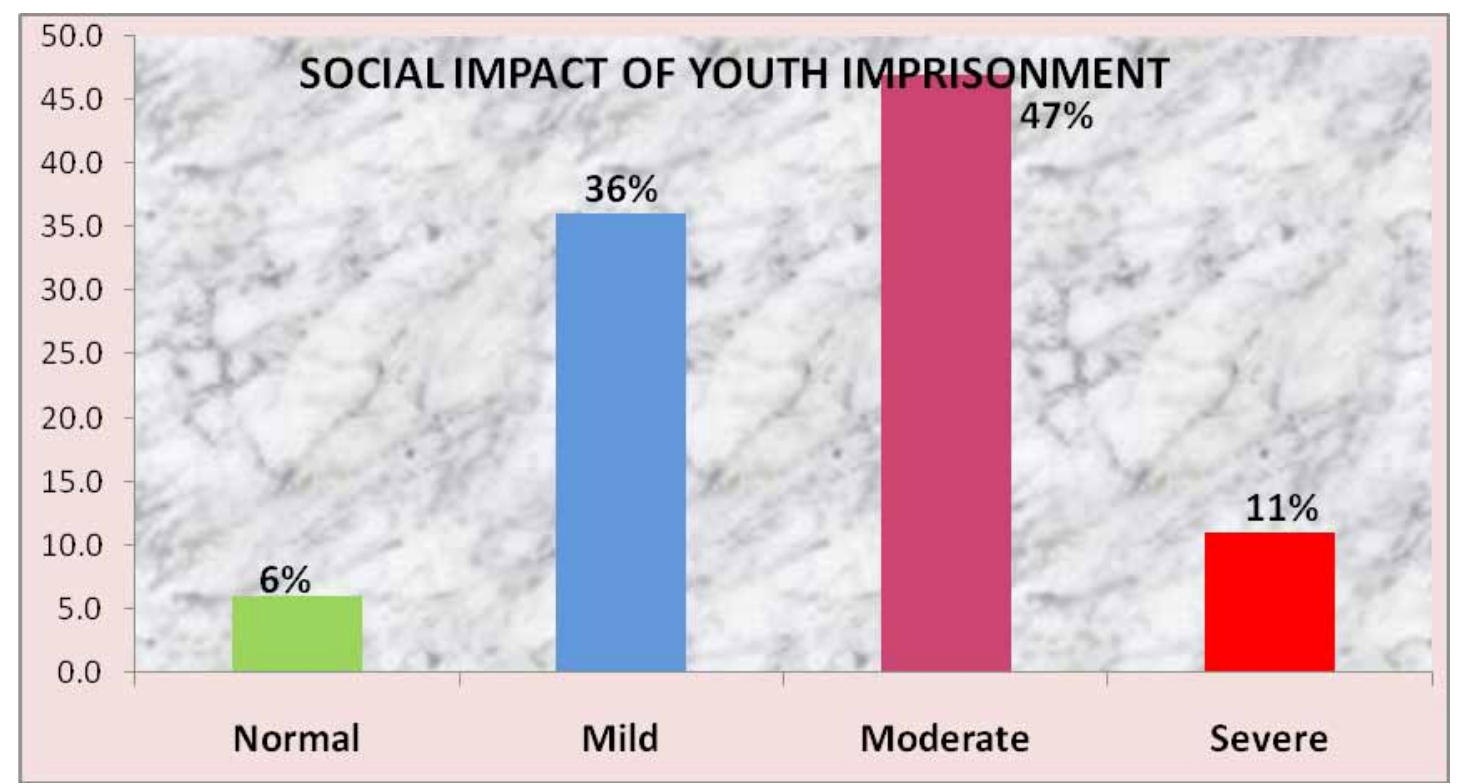

Fig: 2 Showing the Social impacts of youth offenders

Part 5: Youth imprisonment level by the residence and gender of the offenders

The result of t-test revealed that there were significant differences in youth imprisonment level by the gender of offenders $(\mathrm{t}(83)=-8.602, \mathrm{p}<0.05)$. The findings show that there were significant differences between male and female youth offenders in their imprisonment level i.e. more offenders are male.

\section{Discussion}

The finding of the study regarding Educational information of Youth imprisonment reveals that majority of the offenders was those who attended grade 5 to 12 educational level while some offenders were those who have certificate, diploma \& above educational status. From respondents of this study, 26(42.6\%) offenders educational status is not at the level of their interest for 
two main reasons. The first reason is fail (lack of point in order to pass to next educational status) and the second one is due to dropout from school. Among offenders who dropout from school majority of them were dropout due to the economic problem while some of them were due to making crime \& fail in jail, Lack of interest to learn and due to Peer influence.

Similar to the present study, Antonescu and Birau (2014) have found that high school students with a history of juvenile delinquency.

Regarding the Causes of Youth imprisonment, majority $42(50.6 \%)$ offenders main reason to make crime was psychological related causes such as Antisocial personality disorder anxiety and being angry, Uses of substance abuse like alcohol, chat, smoking, and Personal behavior like aggressiveness \& conduct problem while $18(21.7 \%)$ offenders main reason to make crime was social related causes such as bad relationship with parents, broken family (divorce, death of one parent or both, migration), Peer influence and being orphaned; and $23(27.7 \%)$ offenders main reason to make crime was economic related causes such as lack of basic needs due to lack of support and lack of work opportunity.

Similar to the present study, John (2012) studied poverty as cause of juvenile delinquency. Selamawit (2014) study shows that the primary cause of juvenile delinquency in Addis Ababa is poverty, peer pressure, substance abuse, poor academic performance and family dysfunctions.

Findings relating to psychological impacts of imprisonment on youth offenders were reveals that, majority $68(81.9 \%)$ offenders feel diminished sense of self-worth and personal value due to imprisonment while $15(18.1 \%)$ offenders have undecided feelings whether they feel diminished sense or not. Pertaining to beneficial access in the prison, some offenders agree that there was beneficial access to education and psychological therapy and physical treatment in the correctional administration center while some offenders disagree that there was beneficial access to education and psychological therapy and physical treatment in the correctional administration center, and some offenders have undecided feelings to say there was or not.

Majority of the offenders have high level of healthy problem feelings while some offenders have low level of healthy problem feelings. All of the offenders' response reveals that they failed in the feeling of shame and guilt due to imprisonment even if their level feeling is different.

Similar to the present study, Fagan \& Freeman, 1999 study reveals that Young people fall in imprisonment may face many psychosocial challenges. In particular, they are notorious for experiencing educational failure and having problems securing later employment. It is not surprising that incarcerated adolescents have a hard time finding employment as adults, and their contact with the justice system has lasting adverse effects on their legal earnings.

And also Bullis et al., 2002 study reveals that young offenders show worrisome adult outcomes even when compared to other vulnerable groups. The most discouraging comparisons are in the domains of educational attainment and employment. Young offenders use to describe their transition from residential facilities back to the community-only about $30 \%$ of young adults were engaged in either school or work 12 months after their release.

\section{Conclusion}

Research study discovered that the most of the offenders were reported diminished sense of self-worth and personal value due to imprisonment; antisocial behavior, psychological disturbance and emotional instability such as feelings of anger, stress and frustration due to lack of mental stimulation and activity; Investigators intensely endorsing that the Psychological therapy training for professionals in correctional administrative centre and followed by psychological first aid. After availing the training concern offenders will receive the same to stabilize the mental health by reducing their emotional instability. It is more important to reduce the psychological disturbances among offenders and offer affirmative metal health.

Acknowledgement: The authors wish to thank Heads of Dambi Dollo University, Oromia, Ethiopia for their support for completing the Research.

\section{Conflict of Interest: Nil}

Source of Funding: The authors received funding from the Dambi Dollo University for conducting the research and also obtained Permission for Publication of this article.

Ethical Clearance: Ethical Clearance obtained from the Institutional research ethics committee, Dambi 
Dollo University. Written consent was obtained from each participant.

\section{References}

1. Ainsworth, Peter B. Psychology and crime: myths and reality. Longman/Pearson Education: Harlow, England.2000.

2. Andargachew $\mathrm{T}$. The Crime problem and its correction. Volume I. Addis Ababa-University, Ethiopia. 1980.

3. Andargachew T. The Crime and Delinquency and its Correction. Volume II. Addis Ababa UniversityEthiopia Senior essay. 1992.

4. Andargachew T. Crime and Delinquency and its Correction. (2nd ed.), Addis Ababa UniversityEthiopia.1998.

5. Andargachew $\mathrm{T}$. The Grime problem and its correction, Volume II published by A.A.U press. 2004.

6. Antonescu, M. \& Birau, R. The impact of education on juvenile delinquency and its global economic implication. Stanford, CA: Stanford University Press. 2014.

7. Bullis M, Yovanoff P, Mueller G, Havel E. Life on the "outs" Examination of the facility to community transition of incarcerated youth. Exceptional Children. 2002; 69(1):7-22.

8. Clinard, M. B. and Abbott, D. J. Crime in developing countries, a comparative perspective. John Wiley \& sons, Inc: Canada. 1973.
9. Ethiopian National Youth policy, 2004.

10. Federal Democratic Republic of Ethiopia, Central statistical Agency: The Reporter, 2015.

11. Feegan JF, Freeman RB. Crime and work. In: Tonry $\mathrm{M}$, editor. Crime and justice: A review of research. Chicago: University of Chicago Press; 1999; pp. 225-290.

12. Glaser, J., Dixit, S. and Green, D. P. Studying hate crime with the internet: What makes racists advocate racial violence. Critical readings: Violence and the media. Open University Press: Philadelphia.2002; 58: 177-93.

13. Greenberger E. Defining psychosocial maturity in adolescence. Advances in Child Behavioral Analysis \& Therapy. 1984; 3:1-37.

14. John, O. Factors influencing youth crime and juvenile delinquency. International Journal of Research in Social Sciences, 2016, 1(2): 5-19.

15. Selamawit E. Exploring the lived experience of delinquents and young offenders. Addis Ababa University, School of Social Work. 2014.

16. Sisay Z. Causes of Juvinile delinquency. Indira Gandhi National Open University, Ethiopia. 2016.

17. Steinberg L. Psychosocial development in late adolescence: Suggestions for a research agenda. Department of Psychology, Temple University; Philadelphia: 2002 